\title{
Menemenli Tevfik Mustafa Paşa'nın Kırım Harbi Tuna Cephesi Harp Hatıraları
}

\author{
İsmet Sarıbal* \\ (ORCID ID: 0000-0001-2345-6789)
}

\author{
Makale Gönderim Tarihi \\ 24.07.2019
}

\author{
Makale Kabul Tarihi \\ 21.09.2019
}

\section{Özet}

Osmanlı subaylarının modern bir edebi tür olan hatıra yazımına ilgileri Kırım Harbi ile başlamıştır. Kırım Harbi başlangııında Anadolu ordusu komutanlığı yapan Mustafa Zarif Paşa'nın harbin ardından kaleme aldığı hatıraları bir Osmanlı subayı tarafından modern anlamda yazılmış bilinen ilk hatıradır. Batum ordusu komutanı Mustafa Paşa'nın yaverliğini yapıp daha sonra Rusya'ya kaçan Binbaşı Osman Bey'in (Frederick Millingen) Rusça yayımlanmıs hatıraları Kırım Harbi'ne dair bilinen bir diğer hatıradır. Kırım Harbi'nde Tuna Cephesi'nde görev alan Tevfik Mustafa Paşa da harp sonrasında harp hatıralarını yazmıştır. Bu çalışmada Tevfik Mustafa Paşa'nın kaleme aldığı harp hatıraları değerlendirilecektir.

Anahtar Kelimeler: Menemenli Tevfik Mustafa Paşa, Kırım Savaşı, Hatıra.

\section{Menemenli Tevfik Mustafa Pasha's War Memoirs of the Danube Front During the Crimean War}

\section{Abstract}

The interest of Ottoman army officers to write military memoirs that being a modern literary genre, began with the Crimean War. The memoirs of Mustafa Zarif Pasha who commanded the Anatolian army during the Crimean War, were the known first military memoir, which written by an Ottoman officer in a modern sense. The memoirs of Major Osman Bey (Frederick Millingen), who served as the commander of Mustafa Pasha, the commander of the Batumi army and then fled to Russia, is another known memory of the Crimean War, which published in Russian. Tevfik Mustafa Pasha who also

* Dr. Öğr. Üyesi, Çankırı Karatekin Üniversitesi, İktisadi ve İdari Bilimler Fakültesi, Uluslararası Illişkiler Bölümü, ismet@karatekin.edu.tr.

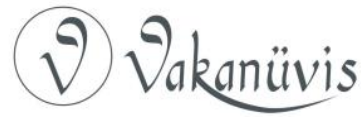


served in the Danube Front during the Crimean War, writed his war memoirs, after the war. In this paper, the war memoirs written by Tevfik Mustafa Pasha will be evaluated.

Keywords : Menemenli Tevfik Mustafa Pasha, Crimean War, Memoir

\section{Giriş}

Hatıra veya başka bir ifadeyle anı bir kişinin kendi başından geçen veyahut tanık olduğu olay ve olguları gözlemlerine, izlenimlerine, bilgilerine istinaden kimi zaman kişisel duygu ve düşüncelerini de katarak anlattığı yazı türüdür ${ }^{1}$. Avrupa edebiyatlarında XVI. yüzyıldan itibaren özel bir tür olarak ilk örnekleri görülen hatıra yazımına Osmanlılar Batı ile temasın arttığı XIX. yüzyılla birlikte ilgi göstermeye başlamıştır. Özellikle 1870'ten sonra hatıra türüne ait yazı ve kitapların sayısı hayli artmıştır. Ziya Paşa'nın Defter-i A'mâl'i, Muallim Naci'nin Medrese Hatıraları ve Sünbüle'si hatıra türünün ilk örneklerindendir. Ahmed Cevdet Paşa'nın Tanzimat dönemini kendi yorumunu da katarak anlattığı Tezâkir ve Maruzât'ı ilk siyasi hatıra örneğidir. Ebüzziya Mehmed Tevfik'in Sultan Abdülaziz devrinin ortalarından 1876'ya kadar geçen süreçteki siyasi olayları anlattığı hatırası Yeni Osmanlılar Tarihi bir diğer önemli siyasi hatıradır².

$\mathrm{Bu}$ dönemde popülerleşen hatıra yazma girişimlerine Osmanlı subayları da dâhil olmuştur. Nitekim 1876-1877 Osmanlı-Rus Harbi'nin doğu ve batı cephelerine ait harekâtın anlatıldığı, çoğu II. Meşrutiyet sonrasında yayımlanan, hayli harp hatırası vardır ${ }^{3}$. Aslında Osmanlı subaylarının hatıra yazma geleneği Kırım Harbi'yle başlamıştır. Kırım Harbi'nin başlangıcında Anadolu ordusu komutanlığını yapan Zarif Paşa'nın anıları bir Osmanlı subayına ait bilinen modern anlamda ilk hatıradır ${ }^{4}$. Yine Kırım Harbi sırasında Batum ordusu komutanı Mustafa

\footnotetext{
${ }^{1}$ Atilla Özkırımlı, Türk Edebiyatı Ansiklopedisi, 5. bs. , C I, Cem Yayınları, İstanbul 1990, s. 111

2 M. Orhan Okay, "Hâtırat", Türkiye Diyanet Vakfı İslâm Ansiklopedisi, C XVI, İstanbul 1997, s. 446.

3 Okay, "Hâtırat", s. 446.

${ }^{4}$ 1816/1817 yılında doğduğu tahmin edilen Zarif Paşa, hatırasında 1830-1860 yılları arasında şahit olduğu olayları ve bu olaylardaki rolünü anlatmaktadır. Zarif Paşa'nın
}

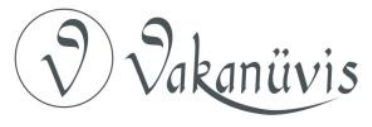


Paşa'nın yaverliğini yapıp daha sonra Rusya'ya kaçan Binbaşı Osman Bey'in (Frederick Millingen) Rusça yayımlanmış hatıraları bir Osmanlı subayı tarafından yazılmış Kırım Harbi'ne dair bilinen bir diğer harp hatırasıdır $^{5}$. Bu iki hatıra yazarının yanına Menemenli Tevfik Mustafa Paşa ismini de eklemek gerekir. Zira Tevfik Mustafa Paşa, Kırım Harbi Tuna Cephesi'ne dair hatıralarını savaşın ardından yazmaya başlamıştır.

\section{Tevfik Mustafa Paşa'nın Hayatı}

Tevfik Mustafa Paşa Adana'nın Menemenli aşiretindendir. Bu nedenle Menemencioğlu/Menemenli lakabıyla da anılır. Paşa, çocuk yaşta aşiretin lideri olan amcası Ahmed Bey tarafından Mısır'a gönderilmiştir. Mısır ordusunun 1832'de Anadolu'yu işgali sırasında Adana'ya gelen Kavalalı İbrahim Paşa, işbirlikçisi Memencioğlu Ahmed Bey'den Mısır sarayında büyütülmek ve tahsil ettirilmek üzere ${ }^{6}$ erkek evlatlarından birini istemiş, Ahmet Bey de kendi çocuklarından birini göndermek yerine açıkgözlülük ederek yeğeni Tevfik Mustafa'yı kendi çocuğuymuş gibi İbrahim Paşa'ya emanet etmiştir?

Tevfik Mustafa Paşa, Mısır sarayında iyi bir eğitim almış, askerlik sanatında kendini yetiştirmiştir. Öyle ki miralay rütbesini alarak

hatırası için bk. Enver Ziya Karal, "Zarif Paşa'nın Hatıratı”, Belleten, 4 (16), 1940, ss. 443-494.

${ }^{5}$ Sir Adolphus Slade, Müşavir Paşa'nın Kırım Harbi Anıları, yay. haz. Candan Badem, Türkiye İş Bankası Kültür Yayınları, İstanbul, 2012, s. VIII.

6 Ibrahim Paşa'nın böyle bir tasarrufta bulunmasının nedeni Mısır vilayetinde tesis edilen zorunlu askerlik sisteminin yapısıyla ilgiliydi. Babası Mehmed Ali Paşa, vilayetinde zorunlu askerlik temelinde bir ordu kurmaya karar verdiğinde Arapça konuşan çiftçi askerlere komuta etmek üzere Türkçe konuşan subaylar atamayı planlamıştı. Bu nedenle Mısır ordusunun üst kademelerinde görev almak isteyen birinin Türk olması yani Türkçe konuşması Anadolu, İstanbul, Arnavutluk ve Osmanlı coğrafyasının diğer bölgelerinden gelmesi gerekmekteydi. Bu subaylar gönüllü olarak Mısır ordusuna katılmak isteyenlerden seçilebileceği gibi bir savaş esiri de olabilirdi. Khaled Fahmy, Paşanın Adamları, Kavalalı Mehmed Ali Paşa, Ordu ve Modern Mısır, İstanbul Bilgi Üniversitesi Yayınları, İstanbul, 2010, s. 239, 241.

7 Taha Toros Arşivi, Dosya No: 640128, http://earsiv.sehir.edu.tr:8080 /xmlui/bitstream/handle/11498/25577/001640128010. pdf? sequence=1\&sAllowed=y, e.t. 10.04.2019.

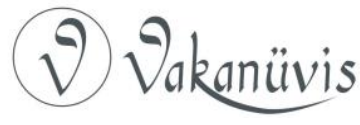


Kavalalı İbrahim Paşa'nın yaverliğine kadar yükselmiştir ${ }^{8}$. Paşa, Nizip Savaşı'ndan (1839) sonra Mısır ordusundan ayrılırak Osmanlı ordusu saflarına geçmiştir ${ }^{9}$. Aslında söz konusu savaştan sonra Tevfik Mustafa Paşa gibi Türkçe konuşan ve de Osmanlı kültürü içinde yetişmiş birçok Türk kökenli subay, Mehmed Ali Paşa'nın isyan etmesi ve Mısır ordusunun Anadolu içlerine kadar ilerlemesi yüzünden ortaya çıkan bir kimlik ve sadakat sorunu nedeniyle Mısır ordusundaki görevlerini bırakıp Osmanlı ordusuna katılmıştır ${ }^{10}$.

Tevfik Mustafa Paşa, miralay rütbesini muhafaza ederek 1841 'de Rumeli tarafına gönderilmiştir. Kırım Harbi'ne kadar geçen süreçte sırasıyla mirliva ve ferik rütbelerini almıştır. Tevfik Mustafa Paşa'nın kariyerindeki dönüm noktası Kırım Harbi'nin ilk evresinde Tuna boyunda yaşanan muharebeler olmuştur. Bu muharebeler sırasında gösterdiği yararlık Tevfik Mustafa Paşa'nın ünlenmesini sağlamış hatta bu yararlılığı nedeniyle ikinci rütbeden Mecidiye nişanıyla taltif edilmiştir ${ }^{11}$. Tevfik Mustafa Paşa, Kırım Harbi'nin ardından İşkodra Mutasarrıflığı'na (Nisan 1857) atanmıştır. Kısa bir süre bu görevde kaldıktan sonra Rumeli bölgesi ferîk-i erkânlığına görevlendirilmiştir. Ağustos 1861'de vezir rütbesiyle Anadolu Ordusu Müşiri olmuş, 1864 'te bu görevinden azledilmiştir. Aralık 1864'te Meclis-i Muvakkat-ı Askerî̀ye memur olmuş, daha sonra 2. Ordu Müşir Kaymakamlığı ve Bosna Kumandanlığı (Kasım 1867) yapmıştır. Bu görevinden azledildikten sonra uzun süre İstanbul'da kalmıştır. 93 Harbi öncesi Meclis-i Tanzimat-ı Askerî ve Meclis-i Muvakkat-ı Askerî̀de görev almıştır. 1877'de Kars Kumandanlığı'na tayin edilmiştir. 1878 yılı başlarında hastalanarak görevinden ayrılmak zorunda kalmıştır. 12 Temmuz 1879 'da vefat etmiştir. Eyüp'te metfundur ${ }^{12}$.

\footnotetext{
8 Taha Toros Arşivi, Dosya No: 551592, http://earsiv.sehir.edu.tr :8080/xmlui/ bitstream/handle/11498/26565/001551669007.pdf?sequence=1\&isAllowed =y, e.t. 10.04.2019.

${ }^{9}$ Mehmed Süreyya, Sicill-i Osmani, C V, yay. haz. Nuri Akbayar, Tarih Vakfı Yurt Yayınları, İstanbul, 1996, s. 1632.

${ }^{10}$ Mesut Uyar - Edward J. Erickson, Osmanlı Askeri Tarihi, Türkiye İş Bankası Kültür Yayınları, İstanbul, 2014, s. 309.

${ }^{11}$ BOA, A. MKT. NZD, 110 / 79, 4 Cemaziyelahir 1270 [ 2 Şubat 1854 ].

12 Mehmed Süreyya, Sicill-i Osmanî, s. 1633.
}

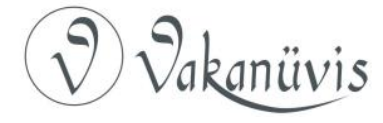




\section{Tevfik Mustafa Paşa'nın Harp Hatıralarının Mahiyeti}

Tevfik Mustafa Paşa, Kırım Harbi'nin ardından harp hatıralarını kaleme almaya karar vermiştir. Paşa, bu kararından dönemin vakanüvisi ünlü tarihçi ve devlet adamı Ahmed Cevdet Paşa'yı da haberdar etmiştir. Ahmed Cevdet Paşa, Tevfik Mustafa Paşa'dan harp anılarına dair yazdıklarını talep edince Tevfik Mustafa Paşa harp hatıralarının bu çalışmaya konu olan ilk bölümünü Ahmed Cevdet Paşa'ya göndermiştir ${ }^{13}$. Ne yazık ki elde mevcut bu ilk bölüm dışında hatıranın geri kalanının akıbeti tespit edilememiştir.

Paşa'nın hatıralarını yazmaya başlamasında Ahmed Cevdet Paşa'nın rolü mühimdir. Ahmed Cevdet Paşa, vakanüvis sıfatıyla Tevfik Mustafa Paşa'dan hatıralarını yazmasını özellikle talep etmiş de olabilir. Bununla birlikte Paşa'nın hatıralarını yazmaya başlamasına sebep olabilecek bir husus daha vardır. Paşa'yı küçük yaşta Kavalalı İbrahim Paşa'nın yanına vererek Mısır'a gönderen Menemencioğlu Ahmed Bey Menemencioğlu Tarihi $^{14}$ adlı kendi anılarını da içeren aile tarihini Paşa'yla yakın bir tarihte (1861) kaleme almıştır. Bu da Tevfik Mustafa Paşa ile Ahmed Bey arasında hatıra yazımı hususunda bir etkileşim olduğu ihtimalini akla getirmektedir.

Tevfik Mustafa Paşa, harp anılarını kendini övmek, birilerini suçlamak, kamuoyu nezdinde kendini temize çıkarmak gibi kişiselleştirilmiş eleştirel hususlar üzerinden kaleme almamıştır. Paşa'nın yaptığı iş, o tarihlerde Avrupalı subaylar için sıradan bir iş hükmünde olan, savaş esnasında yaşananları taktik ve stratejik dersler çıkarılmak üzere paydaşlarına ve umuma aktarmaktan ibarettir. Bu sebeple Tuna Cephesi'ndeki harekâtın stratejik ve taktik detaylarını ve Silistre Muhasarası'na kadar geçen süreçte yaşananları Paşa'nın hatırasında görmek mümkündür.

Tevfik Mustafa Paşa, cephede yaşananları aktarırken hatıra yazımının bir özelliği olarak zaman zaman şahsî değerlendirmelerini de satır aralarında beyan etmiştir. Özellikle harekat alanındaki gayrimüslim ahalinin işgalci Rusları desteklemelerine yönelik eleştirisi

\footnotetext{
${ }^{13}$ BOA, A. VKN, 1/19, 11 Zilkade 1273 [ 3 Temmuz 1857 ].

${ }^{14}$ Menemencioğlu Tarihi için bk. Menemencioğlu Ahmed Bey, Menemencioğulları Tarihi, yay. haz. Yılmaz Kurt, Akçağ Yayınları, Ankara 1997.
}

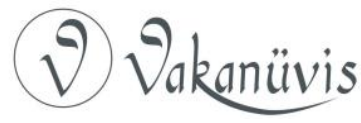


dikkat çekicidir. Paşa, Dobruca'nın stratejik önemine dair değerlendirmelerini layiha başlığıyla ayrıca dile getirmiş ve stratejik bazı öngörülerde de bulunmuştur.

Paşa'nın hatırasını tek düze bir anlatımdan kurtarmak için Tutrakan Muharebesi'nden sonra Serdar-ı Ekrem Ömer Paşa'nın askerlere gönderdiği övgülerle dolu emri ve bu muharebede yararlık gösterip çavuşluktan mülazımlığa terfi eden Mehmed çavuşun kahramanlık hikâyesini hatırasına eklemiş olması da ayrıca dikkate değerdir. Paşa, bir kahramanlık figürü hâline gelen Mehmed çavuşun hikâyesini Hüseyin Hüsnü'nün Saika-i Zafer'i15, Ferik Ahmed Muhtar Paşa'nın Kırım Harbi'nde Silistre Müdafaası ${ }^{16}$, Namık Kemal'in Yüzbaşı Ahmed Nafiz Efendi adına kaleme aldığı Silistre Muhasarası ${ }^{17}$ gibi dönemin kaynaklarından daha ayrıntılı olarak vermiştir.

\section{Metin}

1269 senesi Ramazan'ının gurresinde [8 Haziran 1853] Rumeli'ye memur oldum. Üçüncü cuma günü iki tabur piyade redif ile Saik Şadi vapuruna irkâben Dersaadet'ten hareket ve ferdâsı saat ikide Varna'ya muvâsalat eyledim. Memuriyetim Varna'da ikâmetle vürûd edecek askeri Rumeli ordu-yı hümâyûnu müşîri devletli Ömer Paşa hazretlerinin vaki olacak emri üzere sevke memur etmek idi. Keyfiyeti müşârûn-ileyh hazretlerine yazdım. Taburun birini Silistre'ye ve birini dahi Rusçuk'a irsalini cevap olarak emretti ve bu iki mahalde dörder tabur olmak ve bundan sonra gelecek taburlar doğru Şumnu'ya gönderilmek üzere emir geldi. Bu minval üzere on yedi gün ikâmet ettim. On yedinci günü Rusya Memleketeyn'e girmiş olduğundan diğer iş‘ârlarına kadar vürûd edecek askeri serian kendisine göndermemi mahremâne tarafıma beyan eyledi. Zira müşârûn-ileyh hazretleri sıkışmış idi ve sıkışmasının esbâbı Rusyalı şu aralıkta Memleketeyn'e girmeye başlamış ve bizim hiç sahil-i Tuna'da kuvve-i askeriyemiz yok idi. Hatta Ömer Paşa'nın Şumnu'ya vürûdunda mevki-i mezkûrda bir tabur-ı Dersaadet var idi ve Rusçuk'ta Dersaadet topçularından iki batarya Miralay Emin Bey'le idi. Maazallah Rusyalı egerçi bir on tabur ve iki üç batarya top ile Tuna'yı geçmiş olaydı Şumnu'yu zabt ve teshîr şöyle dursun Balkanlar dahi muhâtaraya düçar olur idi. Binaenaleyh gelen taburların serian irsâlleri hususunu ve Rusyalının

\footnotetext{
${ }^{15}$ Hüseyin Hüsnü, Sâ'ika-i Zafer, İstanbul H 1292, s. 136.

${ }^{16}$ Ahmed Muhtar Paşa, Kırım Harbi'nde Silistre Müdafaası 1853-1854 Tuna Seferi, yay. haz. Gültekin Yıldız - Fatih Tetik, Türkiye İş Bankası Kültür Yayınları, İstanbul 2014, s. 48.
}

${ }^{17}$ Ahmed Nâfiz, Siliste Muhâsarası, Teodor Kasap Matbaası, İstanbul H 1290, s. 47.

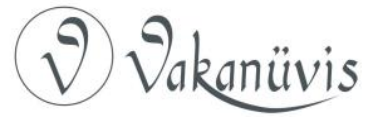


Memleketeyn'e tecavüzünü mahremâne beyan etmiş ve Rumeli tarafından gelmekte olan asâkirin ta'cîllerini te'kîd etmekte idi. Benimle gelen iki taburdan başka daha hiçbir tabur gelmemiş idi. Yirmi ikinci günü yedimde olan talimatı Varna'da bulunan Dersaadet Meclisi mirlivalarından Mehmed Paşa'ya verip serian taraflarına varmaklığıma emir geldi. Derhal yedimde olan evrakı paşa-yı mûmâ-ileyhe vererek iki saat mürûruyla hareket ettim. Yassı Tepe'ye vardım. Orada Ferik Saadetli Halim Paşa hazretlerine tesadüf ettim. O dahi Dobruca'ya memur olmuş gidiyor fakat bu aralık Rusyalı Memleketeyn'e ziyade asker sokmaya başladı. Maazallah yürümüş olaydı karşısında pek az asker bulacaktı. Orada gece kalarak ferdâsı Şumnu'ya vâsıl oldum. Ben varmazdan evvel tecemmü' etmekte olan ordunun meclis-i muvakkatine bu âcizi reis nasb etmiş ve Babıali'ye dahi arz etmiş ve icabı takdirinde sebükbâr fırkası kumandanı tayin edip yani en ileride bulunacak kolordu demektir vardım görüştüm. Tutrakan tarafına Rusyalının hücumu olacağından bahisle riyâset uhdemde olarak mevki-i mezkûrun kumandanlığını uhdeme ihale etti ve bayrama bir gün kalmış olduğundan bayram namazını kılarak mevki-i mezkûra gitmekliğimi emretti. Ferdâsı birlikte Kuziş'e (كوزيش) giderek orada yapılmakta olan istihkâmı gördük. Zira hiçbir yerde el-ân istihkâm olmadığından yeniden yapılmakta idi. Bayram namazını kılarak oradan hareketle üçüncü günü Tutrakan'a muvâsalat eyledim. Benim Tutrakan'a vusûlümde Rusya Memleketeyn'e meydan topu ve muhasara topu ve havan olarak üç yüz elli ve askeri dahi yüz seksen bine iblâğ etmiş idi. Bunu Macarlıdan mülteci bir eczacıyı tebdilen Bükreş'e göndererek orada olan Fransız konsolosundan tahkik ettirdim. Keyfiyeti müşârûn-ileyh hazretlerine yazdım. Onların ki dahi tahkikata mutâbık geldiğinden tahsîn etmiş idi. Tutrakan'da iktiza eden istihkâmları tekmîl ettim. Bir emir geldi. Tutrakan'a dokuz saat ve Rusçuk'a üç saaat mesafe Alina (علينه) nam mahalle istihkâm yapılmak üzere. Gittim keşfettim. Oradan Rusçuk’a gittim. Mahmud Paşa'ya havale ettim. Oradan avdetle Tutrakan'a gelirken riyâset-i memuriyetime gitmeme dair emir geldi. Zira o günlerde harp olmayacak lakırdıları söylenmekte idi. Olduğum mahalden ve memuriyetimden hoşnut olduğumdan orada ibkâmı niyâzen cevap yazdım ve avdetle geldim Tutrakan'a gelerek işimle meşgul oldum. Bir hafta arası geçerek serian memuriyetime gitmeme dair diğer bir emir dahi zuhûr eyledi. Oranın kumandası Mirliva Halid Paşa'ya havalesiyle Tutrakan'da kırk beş gün kadar ikâmetle hareket ve dördüncü günü Şumnu'ya muvâsalat ettim. Defterdarın vesair ümeranın miyânelerinde bazı mertebe burûdet hasıl olmuş ve iş dahi görülmez derecesine varmış olduğundan bahisle memuriyetime devamımı emreyledi. Devama başladım fakat gitmekliğim ve kesb-i kıyas edecek vaktim olduğundan böyle huduttan avdetim nefsime güç gelerek yine avdet etmekliğimi niyâz etmiş idim. İcabı takdirinde yine göndereceğinden bahisle kabul etmedi. Otuz

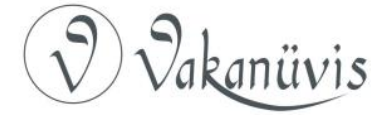


beş gün miktarı oturdum. Bazı mertebe esbâb (?) sıkıştırmış olduğundan ruhsat istedim. Vermeyecek olur ise de ısrar ettim. Ruhsat alarak Tutrakan'a avdet eyledim. Mecliste İzzet Paşa var idi. Onu yerime reis vekil ettiler. Yine riyâset uhdemde idi fakat işbu avdetimde köprü için lazım olacak edevatın tedarikini tarafıma mahremâne sipariş etti. Şumnu'dan hareketle ferdâsı Razgrad'a vardım. Asâkir-i şahaneye zemlik yaptıracağım havadisiyle icap eden keresteyi Razgrad müdürüne havale ve sipariş ederek oradan hareketle ikinci günü tekrar Tutrakan'a muvâsalat eyledim. Bazı mahallere bi't-tekrar istihkamlar yaptırıp fakat bu aralık devletler tarafından Rusyalının Memleketeyn'den çıkması te'kîd olunmakta olup nihayet Muharrem'in dokuzuncu cuma günü akşama kadar mühlet verilerek egerçi çıkmaz ise tecavüzî hareket olunacağı Serdar-ı Ekrem tarafından Gorçakof'a haber gönderilmiş ve işbu haber Tuna sahilinde bulunan kumandanlara dahi taraf-ı eşref-i serdar-ı ekremîden mütevârid olarak egerçi Rusyalı çıkmaz ise karşıya geçerek karakollar basılmak ve tecavüzî hareket olunmak üzere ayrıca emr ve irâde buyrulmuş ve bunun üzerine yevm-i mezkûrda Rusyalı çıkmamış olduğundan ve verilen mühlet yevm-i mezkûrun akşamı saat on ikide hitâm bulmuş idüğinden derhal Tutrakan ahalisinden elli altmış adam bi't-tedârik asâkir-i şahaneden dahi ol miktar neferât hazır ettirilerek akşamdan sonra Tutrakan karşısında olan Rusya karakollarına gönderilmiş ve gece saat ikide karakol-ı mezkûr bastırılarak tarafeynden yirmi otuz el tüfenk atılıp bir iki tanesi itlâf ve bir adedi hayyen tutularak alınan bir miktar eşya ile beraber vukû'-ı hâl serian müşârûn-ileyh hazretlerine arz ve iş'âr olunmuştur. Ferdâsı Rusyalı dahi İsmail'de olan dubalarını İbrail'e geçirmek üzere İsakçı önünden geçirirken haylice muharebe etmiş ise de zikrolunan duba ve vapurlar geçmiştir. Mahall-i mezkûrda Ferik Saadetli Hâlim Paşa hazretleri bulunarak işte işbu iki mahalden muharebeye bede' olunmuştur. Ber-vech-i muharrer İsakçı'dan geçerken vuku bulan muharebede Rusyalının duba ve vapurlarında bulunan askerlerinden bir haylicesi telef olmuştur. İşbu mahalden geçen vapurların çarhlarına İsakçı'dan atılan topların gülleleri ziyan etmemek için dubalarını vapurun yanına bağlamıştır. Bununla vapurlara zarar gösterilmeksizin geçirmiştir. Bundan sonra devletli Ömer Paşa hazretleri otuz sekiz kıta istihkâm topu ile yirmi bir piyade ve bir alay süvari ile Tutrakan'a geleceğini suret-i mahremiyette tarafıma beyan etmiş ve fakat kendisi Rusçuk'a gireceğini ilan ve işâ‘a ederek bunun üzerine doğru Tutrakan'a gelmekte iken iki üç saat mesafe mahalden istikbal olunmuş ve kendisi Tutrakan'a bi'l-vürûd heman istihkâmları gezerek ferdâsı beraberinde olan asâkirin cümlesine bu âcizi umûm kumandan nasb etmiştir. Bu esnada Tutrakan karşısında olan karantinahane ve o havali kendisine ..... olunarak ferdası bi-hikmet-i nurullah hava ziyadesiyle pus olduğundan Tutrakan karşısında olan adaya büyük kayıklar ile asâkir ve mühimmat naklolunmuştur

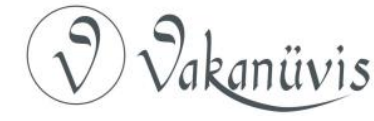


ve geçirilen bir batarya top yani altı kıta top ve iki tabur askerdir. Bunlara Mirliva İzzetli Hâlid Paşa kumandan nasb olunarak adaya asker geçirildiğini ve istihkam yapıldığını pus münasebetiyle Rusyalı duymamıştır. Bir iki gün mürûruyla hava açmış ve bir batarya top ve üç tabur asker tehiyye olunmuş olduğundan evveli emrde Tutrakan'da olan tabyalardan Tutrakan karşısında kâ'in karantina mahalline yirmi otuz kıta gülleli top atıldıkta karantinada olan Rusya karakolları ve zabitanı ve karantina memurları firar etmiştir ve asâkir-i şahane ve top karşıya geçirilmiştir ve mukaddemâ yapılmış olan sepetler dahi tabya imaline mübâşeret birle sepetler dizdirilerek nısf miktarı toprak doldurulmuş olduğu hâlde ferdâsı Rusyalı yirmi iki tabur piyade ve dört alay süvari ve otuz iki kıta top ile gelip geçirilmiş olan askeri tunaya dökmek üzere hemen toplarını indirip işe başlamış ve berrîden dahi ada ve tabyada olan ve Tutrakan sevâhilinde bulunan tabyadan ve Tutrakan'ın sağında olan tabyadan işe başlanılmıştır fakat Tutrakan'ın şimalinde bir mahal var idi yani güzel top atılacak mahal idi buraya üç batarya top getirdim ve burada harbe memur oldum isem de yanımda olan toplara ateş etmedim. Düşündüm ki Rusyalı ileriye gelsin çünkü Rusyalı ileriye gelse sol cenah tamam benim karşım olacağından ateş etmeyerek topları sakladım. Rusyalının ileri geleceğini bilirdim. Zira evvelki top indirip ateş eylediği mahal top menzili olup ve bu kadar piyade getirmiş olduğundan behemehal piyadeyi sevk edeceği ve yürüyüş eyleyeceği malum bulunmuş ve çünkü Rusyalı bir saatten sonra top bindirip ileri kurşunu menziline kadar geldi ve doğrusu bu kadar ateş altında bir hareket eyledi ki hiç fütûr etmedi. Ol vakit yine top endahtına başlayıp taburların dahi sevkine mübâşeret edip ol vakit kemingâhda hıfz eylediğim topları hemen ateş ettirdim ve sol cenahı tamam karşıma geldi. Bu mahalde top olduğunu gördüğü anda oraya yani karşımıza dört top getirip dövmeye başladı. Olduğumuz mahal gülle tutmaz idi. Top arabaları kırılarak bargirleri ve adamları telef olmaya başlayınca topları durduramayarak kaldırdı. Yine bir batarya top getirdi. Bir çeyrek kadar oradan atmış ise de sabit urduramayıp geri çekildi fakat tabya ziyade top atmaya ve taburları yürütmeye bir derece ikdâm eyledi ki tarif olunamaz. Ama benim tarafımdan atılan gülleler sol baştan urup sağ başına doğru giderdi. Müşir Paşa hazretleri dahi bizzat top attırmakla meşgul idi. Bu aralık iki tabur yürüttü. Gerek karantinada olan kurşun ve toptan ve gerek adadan atılan ve gerek Ömer Paşa'nın tabyasından ve sahilde olan topçu Mirlivası İsmail Paşa'nın tabyalarından ve benim olduğum mahalden endaht olunan toplardan yürüyüş eden tabur on dakika müddetde müzmahill oldular. Defa iki tabur dahi sevk ederek ol vakit karantinahane tabyasında olan topların cephanesi kalmamış olduğundan işbu Tutrakan muharebesi bayağı topçu zabitanına şaşkınlık vermiş olduğu şeşhane taburlarının fişenkleri bir topçu çavuşunun hatırına gelerek beher topa onar deste fişek koyup ber-dehân ateş eylediği anda tekrar gelen taburların ikisi

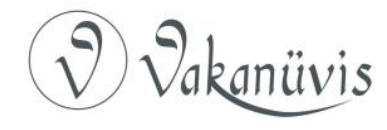


birden müzmahill olmuş işbu muharebede Rusya'nın telefatı bin beş yüz ve mecrûhu üç bin kişidir ve yevm-i mezkûrda Müşir Paşa hazretleri tarafından tevârüd eden evamir-i yevmiye askerince ziynet-bahş eder bir şey olduğundan derc kılınmıştır.

“Bend-i evvel: Ey gayretli topçu bölüğünün yüzbaşısı ve asâkir-i şahane. Dünkü günü karantinanın istihkâmatı tekmil ile devletimizin sancağı ve milletimizin şanı artmak için dikildikten sonra Rusya askeri yirmi biri piyade taburu ve dört alay süvari ve otuz iki piyade ve süvari toplarıla iftihar ettiğimiz ve muhafazasını vazife-i zimmet bildiğimiz sancak üzerine hücum etti. Sizin dindarlığınız ve kemâl-i gayret ve şecaatiniz buradan atılan topların ianesiyle karantinadaki üç tabur piyade ve altı kıta top böyle cesim kuvvetle hücum eden düşmanı bütün bütün münhezim ve perişan ve geldiğine pişman eyledi. Bend-i sânî: Düşmanın her ne kadar lâşesi olduğunu ve her ne kadar mecrûhu olup taşıdığını sizin gözleriniz gördü ve benim keşfim iktizâsınca bin beş yüz askerini telef ve idam ve üç bin kişisini mecrûh eylemişsiniz. Bend-i râbi': İşte böyle din ve devlet uğruna gayûrâne ve şecîâne siz gibi muharebe eden askerin hasmı daima böyle makhûr ve telef ile cümlenizin kuvvetdârınız bulunduğum hasebiyle cümlenize velinimet ve peygamber efendimizin vekili olan padişahımız efendimizin nâm-ı nâmî-i şehrîlerinden selam-ı mahsus ile vaki olan gayretinizi kemal-i teşekkür ve memnuniyetle tahsîn ederim. Hak te'âlâ hazretleri cümlemizi padişahımıza bağlasın ve böyle sadakat ve gayret üzere hizmette bulundukça berhudar eylesin. Bundan böyle dahi sizden yine bu suretle gayret ve şecaat zuhûrunu me'mûl-i kavî etmekteyim. Göreyim sizi herhalde namusa himmet ve gayret edesiniz ve cümlemiz bu halde bulundukça Allahu te'âlâ hazretlerinin inâyet ve ihsânı ve peygamber efendimiz hazretlerinin imdat ve rüçhanı ve padişahımız teveccühatı ile bizim karşımızda dayanacak düşman yoktur. Daima böyle münhezim ve perişan olacağına şüphe etmeyip mâdâm ki ibtidâki muharebede böyle berbat ve perişan olmuştur bundan böyle avn-ı hakkla karşımızda durup asla sebât edemeyeceği derkârdır. Hemân cenâb-ı mevlâ-yı müte'âl daima muvaffakiyetler ihsan buyursun. Amin. / 3 Safer 1270 [5 Kasım 1853] / Orduyı hümâyûn-ı Rumeli."

Doğrusu çavuşun bu bâbda olan hizmeti tahsîn-i sitâyiştir. Bunun üzerine Rusya bozularak felillâhi'l-hamd sûret-i galebe tarafımıza vaki olmuştur. Çavuş-ı merkûmu devletli Ömer Paşa hazretleri mülâzım etmiş ve beşinci rütbeden bir kıta mecidiye nişân-ı zî-şânı dahi vermiştir. İşbu çavuş mülâzım olduğu hâlde muahharan Silistre Muhasarası'nda bulunarak Rusyalı bir gün Arap tabyasına hücum etmiş ve bir binbaşı bir miktar neferi girip tabyada olan toplardan birinin üzerine mezkûr binbaşı çıkarak mülâzım-ı mûmâ-ileyhe bir kılıç urduğu anda mülâzım dahi binbaşıya bir seyf-i Muhammedî urup helak

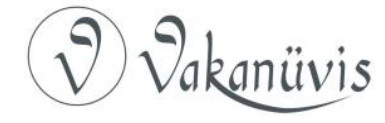


etmiş ve mülâzım-ı mûmâ-ileyh dahi o anda şehit olarak doğrusu dîn-i Muhammedîye çok gayret etmiş ve bir cesur zat imiş. Şu mülâzımın hakkı malum olmak için bu kadarca iş'âr olunmuştur. İşbu Tutrakan Muharebesi'nin ferdâsı Rusyalı bir iki saat geriye çekilerek ikamet etmiş ise de hayli askerini gizlice Eflak içine çekmiş ve bir miktar ile karşımızda ikamet etmiştir. Bunun haftası gecesi Tutrakan karşısında olan karantina istihkâmında bulunan askerimizi Müşir Paşa hazretleri Tutrakan karşısında olan adaya çekip adadan Tutrakan'a geçerek karşımızda karantinada olan lağımlarımıza ateş vermiştir. Bunun üzerine geri çekildiğimizi Rusyalı duyarak karantinaya bir hayli adam göndermiş ise de Müşir Paşa hazretleri top endaht ettirerek durdurmamıştır. Adada olan askerimizin üzerine birkaç gün gelip istikşâf etmiş iseler de hiçbir şeye muvaffak olamamıştır. El-hâsıl müşârûn-ileyh hazretleri Tutrakan'a geldiğinin otuz altıncı günü Şumnu'ya avdet buyurup mevcut olan asâkirin bir miktarı Rusçuk'a ve bir miktarı Silistre'ye ve bir miktarı Tırnova'ya ve birazı Şumnu ile mahall-i saireye sevk ederek yedime talimat verip zaten dahi mingayr-i haddin umûm kumandan bulunduğum hasebiyle bunları dahi havale etmiştir. Bunun üzerine kış dahi gelmiş ise de felillâhi'l-hamd talimatı mûcebince icra olunup üç tabur asker ile kışlamak üzere bizi dahi Yenipazar’a göndermiştir. Ama Deli Orman nâm mahalle mürûr edinceye kadar hayli meşakkat çekilmiştir. Üçüncü günü Yenipazar’a vâsıl olup vürûdumdan bir hafta sonra Şumnu'ya celb ile Şumnu'da olan askere umûm kumandan etti. Bu aralık Dobruca Kumandanı Vezir Hasan Paşa kırk tabur asker ve dört batarya top ederek bununla ve yanında olan asker ile karşıya geçip İsmail'in Kalas cânibinde olan gölün yanından Tuna'yı mürûr ile gölün tûlü olan otuz dört saat mesafesini devr ederek İsmail'i muhasara edip almak emelinde olduğunu ve bunun için birkaç defa kâğıt yazdığını bir gün ümerâ-yı askeriye mevcut oldukları vakit Müşir Paşa hazretleri söyledi ve re'yini tahsîn etmedi ve esbâbını beyan etmemiş ise de şöyle dedi ki İsmail Kalesi metin bir kale olup arîz ve amîk muhasaraya ve muhasara toplarına ve külliyetli askere muhtaç olduğundan beyan olunan günü devr ederek gitmek envâ'-ı muhatarayı mûcib olacağını ve asker Tuna'yı geçtikten sonra Rusyalı arkasını Kalas tarafından kat' etmesi âsân olacağını ve bundan başka Rusya'nın elli adet duba ve sekiz adet vapuru olup bizim ise bunlardan hiçbir tedârikimiz olmadığından ve köprümüz dahi bulunmadığından işbu hareketin icrası adîmü'l-imkan olduğu nümâyândır. Buralardan bir miktar bahisden sonra benden ötürü Mustafa Paşa benim efkârımı bilir onu memur ederim dedi. İki gün mürûruyla beni celb ederek âcizâne vuku bulan hizmetimden beyan ile mükâfat olarak ikinci rütbeden bir kıta Mecidiye nişân-ı zî-şânî ita eyleyerek Dobruca'ya kumandan edip Yenipazar'da olan üç tabur hassa ile bir batarya top verilip memur etti ve ikinci günü memuriyetime gitmek üzere çıktım. Yenipazar'a vardım askerde hastalık zuhûr etmiş olduğundan hastalarını bi't-tefrîk Şumnu'ya ve bâkîsi ile

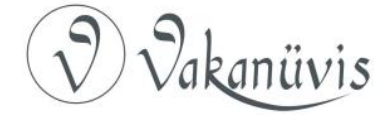


topları alıp yedime vermiş olduğu talimatı mûcebince Maçin'e müteveccihen azîmet ettim. Kış mevsimi olarak yani erba'în olduğundan yevmiye nihayet dörder saat giderek Maçin'e muvâsalat olunarak asker ve toplar arkamdan birkaç gün sonra geldi. Yetmiş senesi Rabiülahir'inin on ikinci perşembe günü [12 Ocak 1854] Rusyalı Kalas karşısında vaki Zatofa'ya (زاطوفه) bir vapur ve üç kıta tüccar sefinesiyle asker geçirmiş ve Zatofa'da olan tarassud karakolunu ihrâk ederek yine askerini sefinelere ve vapura koyup mahall-i mezkûrun yarım saat yukarısında Kızaklı nâm mahalle askerini çıkararak karye-i mezkûre Tuna sahilinde olmak hasebiyle ahalisi geride olan karyelere çekilmiş olduğundan karye-i mezbûrenin birazını ihrâk etmiş olduğunu tarassud karakolları tarafımıza haber vermiş olduğundan der-akab bir tabur piyade ve iki bölük süvari ve bir miktar asâkir-i muvazzafa ve iki kıta süvari topu ile Miralay Ali Bey'i memur ve i'zam ettim. Ve ben dahi kuvve-i kâfiye istishâb ederek azîmet eylemiş olduğumdan Rusyalı geri çekilmiş ve ferdâsı günü karşımızda olan adada hayli piyadesi ve bir miktar süvarisi görünmüş ve bu adada Rusyalı bir iki mahdan beri bekleyerek hatta bir istihkâm dahi yapmış olduğundan hemen bir tabur piyade ve yüzden mütecâviz ahali adaya geçirilmiş ve Tuna'nın beri yakasında dahi iki süvari topu ve beher topun yanında ateş üzere dörder bölük piyade tayin olunarak salifü'z-zikr karşıya geçirilmiş olan tabur bu topların sırasınca hareket ettirilmiş ve Rusyalı iki tabur şeşhaneci ile karşılayarak emr-i muharebeye mübâşeret olunup ve beri taraftaki topların ve toplar yanında bulunan piyade bölükleri ateşe başlayıp emr-i muharebe iki saat miktarı mümted olarak ba'dehû Rusyalı tâb-âver olamayarak istihkâmı olan mahalle kaçmış olduklarından asâkir-i şahane takip ederek istihkâma takarrüb eylediklerinden Rusyalı istihkâmı dahi terkle firar etmiş ve asâkir-i şahaneden birkaçı Rusyalının istihkâmı üzerine çıkmış ve biraz silah dahi alınmış ise de asâkir-i şahanenin ol tarafta gecelemesi caiz olamayacağından beri tarafa geçilmiş ve işbu muharebede Rusya'dan yüz elli kadar telefât ve asâkir-i şahane tarafından dahi dört şehit ve yirmi üç yaralı ve asâkir-i muvazzafadan üç yaralı vuku bulmuştur. Rusyalı tarafından mezkûr ada içinde göl üzerine kurulmuş olan köprü dahi tahrip olunmuştur.

\section{Başka bir fıkra dahi ilave olunacağı cihetle burası bir miktar açık bırakıldı}

Bir hafta mürûruyla Tulca'dan Boğazköyü'ne kadar Tuna sahilinde olan istihkâmlar yolunda olmadığını tahkîk eylemiş olduğundan bunları bizzat gezip icabına bakılmasını tarafımıza iş'âr ederek yerime asâkir-i Mısırıye-i şahane mirlivalarından Hırsova Kumandanı İbrahim Paşa'yı tevkîl edip erkân-ı harbim ile çıktım. Kâffesini gezip icap eden mahallere yeniden istihkâm yapılmış fakat Maçin'e vusûlümde Ibrail'in karşısında yani bizim tarafta Putyaşi (يوطه يا شى) nam mahal tabya yapılmaya şâyeste bir mahal olduğundan çünkü bunun önünde Tuna darlaşmakta olarak dubaları buradan geçirmekte 
bulunacağından yukarıya yani Hersek ve Boğazköy taraflarına duba geçirip tazyik etmemek için bir istihkam yapılmak muhassenâtı câmi' olduğundan ve Müşir Paşa hazretlerinin dahi emirleri bu merkezde bulunduğundan mahall-i mezkûra istihkâm yapılmasına şurû' olunmuş ise de işbu mahallin karşısında Rusyalının istihkâmı olup bizim tarafa adem yaklaştırmak imkanı olamadığından fırsat gözetilerek hava ziyadesiyle kışlamış olmasıyla bir yerden bir taraf görülmemekte bulunduğundan bir gece üç tabur asâkir tedârik ve tehiyye olunan levâzımât ile me'an sevk olunup sabah karîb oldukta askeri geriye alarak bir hafta zarfında bir tabya yapılarak asker ve top ikâme olunmuş ve bir taraftan dahi istihkâmı ziyadeleştirmekte olarak kendim bâlâda hâmegüzar-ı iş‘âr olunduğu üzere mevkiyi gezerek Tulca'ya vusûl buldum. Bir saat mürûruyla Maçin tarafından top sadaları geldi. Ferdâsı mahsus-ı yaver ile muharebeye bede' olunmuş olduğunu tevkîl olunan ibrahim Paşa'dan bâtahrîrât haber aldım. Tulca ile İsakçı arasında vaki Çatal nâm buruna bir tabya imal olunup dubaların İsmail'den beri cânibe geçmesine mâni olunması Müşir Paşa emir buyurmuş olduğundan Tulca'ya vürûdumdan evvelce erkân-ı harp gönderilerek keşf ile inşasına bede' ettirilmiş ve ferdâsı mahall-i mezkûru keşf etmek üzere nâçâr Tulca'da kalınarak gidip icap eden mahallere tekrar istihkâm verilmesine karar verilerek erkân-ı harp zabitanı konulmuş ve oradan avdetle ferdâsı İsakçı'ya muvâsalat ve orada olan istihkâmlar dahi görülüp bazı mertebe lüzum görünenlerin ilavesi kumandanına sipariş ile oradan hareket ve merkez-i kumandan olan Maçin'e muvâsalat olunmuştur. Putyaşi'nde olan tabya karşısında İbrail sahilinde Rusya'nın mukaddem yapmış olduğu tabyayı cesâmetlendirerek harbe mübâşeret etmiştir. İşbu muharebe küll-i yevm olup geceleri dahi yarım saatte bir kere kırk dörtlük kumpara atar idi. Bu esnada Kalas'da dahi köprü imaliyle meşgul olup fakat Kalas'da askerî olarak üç dört tabur askeri var idi. Rusyalının bu tarz hareket-i tecavüziyesine yirmi gün kalarak asker ve top bataryaları çoğaldı. Ve re'yü'l-ayn görür idik ve tecavüz etmek üzere olduğunu serdar-ı ekreme inhâ etmiş idim fakat Babadağı bir sarp mahal olduğundan istihkâm verilse ve birkaç aylık zahire iddihâr olunsa ve icabında tahassun edilse güzel olacağını dahi beyan etmiş idim. Bir zaman mürûruyla Babadağı'na zahire iddihârına dair emirnâmesi geldi ve bunun üzerine Tulca kaymakamı Istabl-ı âmire pâyelilerinden Osman Bey'i memur ettim ve şu aralık Rusyalının tedârikât-ı külliyesi müşâhade olunmakta olduğunu ve tecavüz ederse tâb-âver olunamayacağını dahi beyan ve inhâ eylemiş idim. Mukaddem yedime vermiş olduğu talimatta dahi Rusyalı tecavüz eder ise ric‘at olunması münderic bulunduğundan yine bu mealde emirnâmesi geldi. Sonra kendileri dahi iane için miktar-ı kâfî asker ile hareket ederek Silistre tarîkiyle gelmekte olduğunu beyan eylemiş ve bu aralık İbrail'de dahi köprü inşasına mübaşeret eyleyerek Putyaşi istihkâmımızı derece-i nihâyede sıkıştırmaya başlamış ve Putyaşi tabyasından İsakçı'ya

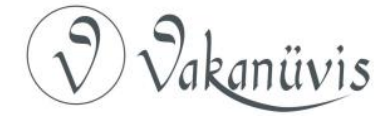


doğru bir tabya dahi yaptırılmış idi. Bundan dahi mukaddem duba ile Kalas'dan gelip Putyaşi tabyasını sıkıştırmakta olduğundan dubalar geldikte Putyaşi'nden ve işbu tabyadan biz dahi sıkıştıracak iken bir sabah vakt-i şafakta beş tabur asker ile ve gemilerle gelip geçip tabyamızı bastı. İki buçuk saat muharebeden sonra inâyet-i bârî ve imdâd-ı ruhaniyet-i hazret-i peygamberî tâb-aver-i mukâvemet olamayarak gemilere râkiben ve münhezimen gitti. Bu muharebede Rusyalının yüz elli adamı tabyamız önünde kaldı ve hayli tüfenk ve eşyâ-yı saire dahi bıraktı. Bundan sonra Rusyalı cerî̀ sıkıştırarak gece ve gündüz Putyaşi istihkâmımızı bırakmadı. İşbu iki gün Putyaşi'ne nısf köprü içinde bir batarya top ve beş top askeri ve küçük kayıklarla dahi bir miktar asker geçirip bu esnada mukaddem kırmış olduğu söğütlük Kalas'ın karşısı olduğundan altı vapur ve büyük sekiz kıta tüccar sefineleri ve yirmi otuz miktarı sandallarla geçirmeye başlayıp yine yevm-i mezkûrda otuz beş top ile ve iki tabyadan ve otuz miktarı top ile Çatal tabyasını dövmeye başlamış ve iki üç saat şiddetle dövdükten sonra ve tabyamızı gereği gibi fenalaştırdıktan sonra iki vapur arkasında iki kıta top İsmail'den getirerek ve Çatal tabyasının ateşine bakmayarak Tulca tarafına geçirip hemen köprüleri kurup Tulca'nın önünde olan ada ki Rusyalının toprağıdır iki alay süvari ve birkaç adet tabur Çatal tabyasıyla Tulca mâbeynine geçirerek Çatal'a karadan dahi hücum edip içinde mustahfız olan bir buçuk taburdan yüz adem miktarı kalıncaya kadar muharebe ederek sonra işbu yüz ademden altmış miktarı firar ve bâkîsi kumandanıyla nâçâr teslim olmuşlardır. Yevm-i mezkûrda yine Tulca'nın iki saat aşağısında olan mahalden dahi üç tabur sevk etmiş ise de bu sahte bir hareket olarak akşamı yine geri almıştır. Bunun emsâli arkamızda olan Hırsova'ya dahi pek çok ateş edip hücumlar göstermiş ise de bu dahi sahte olaraktır. Gelelim Kalas'tan geçirdiği yüz kıta top ve seksen adet tabur olup yirmi bine karîb oldukta sahilce sevk ile o dahi Putyaşi'nin Maçin ile olan ihtilâtını kat' etmek üzere sevk eyleyerek Putyaşi karşısına geçirmiş olduğu asâkiri beş altı defa hücum etmiş ise de muvaffak olamayarak sekiz saat miktarı muharebeden sonra toplarını terk ile askerini alıp karşıya geçirmiştir. Putyaşi'nde bir taburundan ziyade telefât ve Çatal'da beş taburu helâk olmuştur. Hatta tabya hendekleri lâşe ile doldurulup üzerinden asker geçirmiştir. İşbu dubalarda yirmi ikişerlik Paixhans olarak üçer top ile iki beş kıyyelik top vardır. Bu hesab üzere ___ sefinelerde top ve tabyalarda dahi tahminen top ki cem'an top ile bir gûnâ ateş etmiştir. Bundan başka altı adet vapuru ve beher vapurunda sekizer büyük Paixhans vardır. Dubalarda olan toplar mil üzerindedir yani istediği mahalle çevirir. Tuna'da elli adet duba ile on adet vapuru vardır. Bizim ol vakit on yedi bin askerimiz olarak bu dahi Boğazköy, Hırsova ve Hırsova ile Maçin mâbeyninde ve Maçin ve İsakçı ve Çatal ve Tulca'da idi. Boğazköy Hırsova'ya dokuz saat ve Hırsova'nın maçine on iki saat

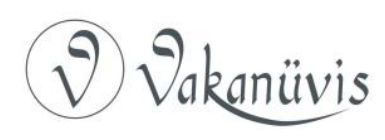


Maçin'den İsakçı altı ve İsakçı'dan Tulca altı saat ki cem'an otuz üç saat mahalle münkasim ve bunların önünde Rusyalının istihkâmıyla askeri, topları var idi. Bunların birbirlerine ianeleri adîmü'l-imkân olup Rusyalı ise Kalas'tan ve Çatal'dan yüz miktarı top ve seksen bin askerle geçti ve daha ziyade idi. Egerçi bu miktar var mıydı deyü bir zan gelir ise Rusya kumandanı Gorçakof gazete ile ilan etmişti. Rusyalının ol vakit çıkardığı gazetelerine müracaatla şüpheden âzâde olunur. İşbu Dobruca daima Rusya'nın tecavüz edeceği mahaldir. Zira İsmail'in karşısı olduğundan kendi vilayetine yakın olmağla mühimmat ve zahire nakli âsândır. Dobruca ise mahsüldar mahaldir. Kırk elli bin askeri daima besler ve hatta ekser mahalleri çayırlık olmağla süvari beslemeye zahmet çekilmez. Çünkü asker sevki buna muhtaçtır. Binaenaleyh şu Dobrucaya ziyade dikkat etmek farîzadandır. Zira birinci hücum ve tecavüz edeceği mahal burasıdır. Burasını tecavüz ettikten sonra Rusya'yı Balkan'dan başka zabt edecek mahal yoktur ve Balkan'a geldikten sonra reaya dahi güç tutulabilir zira ricat vukuunda gördüm hiçbir reaya gelmedi cümlesi Rusya'yı karşıladılar fakat Hacıoğlupazarı reayası ehl-i İslâm ile hareket edip bunlar mukaddem dahi seferlikte ehl-i İslâmdan ayrılmamıştır. Bunlar bizi sevdiğinden ise bir miktarı dahi hareket etmeseler belki yağma olurlar içindir mamafih bu dahi câ-yı dikkattir. Harpten evvel ehl-i İslâm dahi bu seferlikte vatanlarını terk etmezler deyü söylenir ve işitirdik. Lakin rabbim zeval vermesin ehl-i İslâma ve rabbim Devlet-i Aliyye'yi daim eyleyerek a'dâsı üzerine galip eylesin devletinden ayrılmayacakları derkârdır. Zira işbu Dobruca'nın esbâb-ı muhafazasına dair lâyiha-i efkâr-ı âcizanemin beyanını şurada münasip gördüğümden ber-vech-i âtî beyan olunur.

Şöyle ki birincisi bâlâda hâmegüzâr-ı iş'âr olunan müdafaa âdeten evvel olduğu misillü kalalar inşa olunarak Babadağı dahi merkez ittihaz kılınarak bir büyük debboy yapmak lazım gelir. Zira Babadağı mevâki'in her birine yakındır. Babadağı'ndan gerek zahire ve gerek asker sevki esheldir. Kendisinin ormanlık içine iki boğazı vardır. Tulca tarafında olan pek de boğaz değil ise de istihkâm ile zabtı mümkündür ve diğer boğazı ise tabii pek müstahkemdir. İcap eden mahallerine bir kat daha istihkâm verilir ise geçmek mümkün olamaz. Rusya işbu kaleleri terk ile aralarından geçip ileri hareket olunamaz etmiş olsa bize hizmet etmiş olur ve bu kalelerin dahi zabtı hayli vakte muhtaçtır. Kale olduğu gibi Babadağı'ndan iane pek esheldir. Bi'l-farz bu kaleleri hüda etmesin almış olsa yine Babadağı gibi bir cesim istihkâmımız olduğu hâlde bunu dahi terk ile gidemez zira gitmek farz etsek işbu kuvvet ile Şumnu ve ilerimizde olan kuvvet miyânesinde kalır. Bizim taraf harbi kabul etmeyip tahaffuzda Rusya yine kifâyet eder fakat arkasından gelen zahire ve mühimmat tarîkini kat' eder. Bu cihetle Rusyalı kendi kendisine perişan olur ve bir de Doburca'da büyük sular olmadığından bir kolorduyu birden sevk etmek mümkün değildir. Ol vakit sahil-i Tuna'ca gitmeye muhtaç olur. Bu cihetle Hırsova ve Boğazköy kaleleri

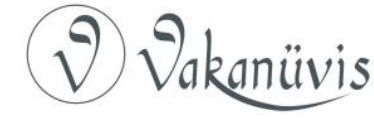


önünde olacağından onlar ile işbu Babadağı kuvveti arasında kalır ve bu ise fenn-i harpçe pek büyük dikkat olunacak mahaldir. Ama behemehâl Babadağı ve Tulca ve İsakçı ve Maçin buraları zabt etmeyince hareket edemeyeceği derkârdır. Bu tarafa geçmek ise çünkü bâlâda otuz üç saat deyü iş'âr olunan mahal kestirme tarîkiyledir yoksa sahilce seksen saata karîbdir. Maçin ile İsakçı arası altı saattir. Ama Tuna'nın girintisi ve burunları çok olduğundan sahilce on yedi saattir. Harbiyeye müracaatla malum olur. Binaenaleyh her noktaya asker ikâmesi mümkün olamayacağından istediği mahalden mürûr eder ama kaleler var iken ileri hareket edemez. Zira bu kalelerde olan asker verâsından ve kaleden hurûc ile düşmanı sıkıştırır. Mukavemet edemediği halde kaleye tahassun eder. Babadağı'nda olan kuvvet ile dahi karşılar. Şu hareketle Rusya tecavüz edemez veya uğraşmaya mütevakkıftır. Egerçi muahede iktizası (sevâhile kale inşası ahden uyamayacağı müttehaz ve iş'âr olunmuş ise de mukaddemki muahedededir şimdi bu muahede münfesih olmuştur. Binaenaleyh behemehâl istihkâm yani kale yapılmak lazım gelir) sahile kale inşası uyamaz ise de Babadağı'nda ber-minval-i meşrûh istihkâm verilip ve asker dahi ikâme ettirilip bâlâda esâmisi iş'âr olunan sahile cüz'î miktarı asker ikâmesiyle bir ileri karakolu gibi tutmak ve Rusya herhangi noktadan mürûr edecek olur ise derhal cümlesi onun karşısına gelerek Babadağı'ndaki kuvvet dahi bunlara zam olunarak icabına göre meydan muharebesi yani icabına göre demektir olmadığı hâlde Babadağı'na tahassunla Rusya ileri hareket edecek olur ise verasından gidip harp etmek ve mühimmat ve zahiresi tarîkini kat' etmek hizmetleriyle meşgul olmak ve bu sırada yani madem ki sahilde istihkâm olmadığı hâlde Karasu mahalli tutulmak lazım gelir. Şöyle ki Tuna sahilinde Boğazköy'den alarak Karasu’ya gelinceye kadar bir göl vardır. Binaenaleyh tabii müstahkem demektir ve Karasu'da bir köprü vardır. Oradan düşmanın geçmesi lazım gelir. Orasına müsteselsil tabiyeler inşasıyla tutulabilir fakat Karasu'dan Karadeniz'e kadar dört saatlik bir mesafe vardır. Ama Babadağı'nda asker var iken ve Karasu'da dahi böyle istihkâm mevcut iken bu ikisinin arasına düşmanın girmesi muhâldir. Bu sırada Boğazköyü'ne dahi bir büyük istihkâm yapılabilir. Bu cihetle yine Rusya egerçi geçmiş manevrasını yani buradan tecavüz etmek murad eder ise bize hizmet etmiş olur. Bu cümle ile beraber Tuna sınırının muhafazası lâekall yirmi kıta top şalopalarından mürekkeb bir donanmamızın vücuduna tevakkuf eder. Zira düşman Tuna'nın şatt-ı yessârına sefer toplarından mürekkeb tabyalar nasb ettikte tarafımızdan iki kat menzilli büyük toplar kullanılsa onun tabyalarına sekte vereceği ve onun tabya himayesinden mahrum olması nehir geçidi icrasına mâni olacağı derkârdır. Ve lâsiyyema şalopalar içinde müteharrik ve seyyar bulunan altmış kıta büyük top karadan kaleler içinde olacak altı yüz kıta topun makamına kâ'im olur. Düşmanın sâlifü'l-beyân ordusu hey'et-i Tulca'dan ve Kalas önünden ve Putyaşi'nden beriye mürûru mukarrer

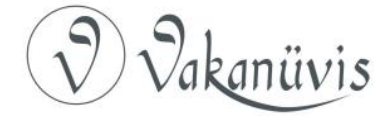


olundukta bu mevâki'-i muhtelifede yirmi dört saat mukâvemet olunduktan sonra Tuna sahilinden ric'at etmekliğimiz talimatı cenâb-ı serdar-ı ekremî iktizasından bulundu ve gece saat bir sularında düşmanın ateşine ârâm gelmekle Putyaşi tabyasından hareketi belli etmeyerek Maçin'e ric'at kılındı ve İsakçı ve Tulca mevkilerinde bulunmuş olan asâkir-i şahanenin Babadağı üzerine çekilmeleri kumandanları bulunan mirlivalar İslâm ve Osman Paşalara tahrîr olundu. Çünkü serdar-ı ekrem hazretleri sekiz tabur asker ve sekiz kıta top ile Silistre'ye teşrif buyurmuş olmalarıyla bizim Babadağına doğru ric'atimizi ve orada kendilerinin dahi gelip bize inzimâm edeceği düşman içeriye doğru yorar ise orada bir meydan muharebesini kabul eyleyeceğini yâver-i harp irsâliyle bildirmişti. Ertesi gün hareketimizi ol niyetle icraya bede' ve mübâşeretimiz üzerine diğer bir yâverin gelip re'yen Babadağı'ndan Karasu Boğazı üzerine tahavvül etmiş olduğu emrini tebliğ eyledi. İcap edenlere yani Babadağı'na ve İsakçı ve Tulca müfrezelerine Karasu'ya sevke inat eylemeleri haberi gönderilip Hırsova'da müstahfız olan Mısır Mirlivası Ibrahim Paşa'ya kumandasında bulunan iki tabur ve altı kıta top ile Hırsova himmet-i hareket etmeyip orada sabit kalması tenbih olundu. Zira kolordunun külliyetli bakiyyesi Hırsova hizasını tecavüz edinceye değin mahall-i mezkûrdan Tuna’yı mürûra müheyyâ bulunan birkaç tabur a'dânın beriye geçip yolumuzu kat' etmesi bir emr-i mahzurdur. İbrahim Paşa'nın Hırsova geçidini beklemesi lazım gelmişti. Hareketimizin üçüncü günü Hırsova sahrası tayy-ı ubûr olundukta paşa-yı mûmâ-ileyhin dahi terk-i mevki birle Karasu'ya sürat-i vürûdu kendisine emr olunarak Karasu'ya vürûd olundu. Orada bütün kolordunun ale't-temâm tecemmü etmesi ve Dobruca'nın kâffe-i ahâli-i İslâm'ının dahi toplandırıması yirmi dört saat içinde resîde-i hüsn-i husûl oldu. Burada cenâb-ı serdâr-ı ekremîden gelen emirnâme Şumnu'nun merkez-i orduyu hümayun olmasıyla onun muhafazası her şeyden akdem elzem olduğu beyanını şâmil ve kendisinin maiyyetindeki sekiz tabur ile beraber Şumnu'ya azîmet buyurdukları hikâyesiyle bizim dahi doğruca Şumnu'ya gelmemiz emrini müştemil bulunmağla biz de Karasu'dan hareket ve düşmanı çevresi boyunca bir kol üzere rıhlet olundu. Fi'l-vaki seferin hengâm-ı ibtidâsında maslahatı bir meydan-ı vakanın ikbâli ve idbâr bahsine ta'lîk etmekten ise düşmanı Silistre ve Varna kaleleri muhasarasına mecbur etmek ve üssü'lharekatımız olan Şumnu'ya yakın getirip orada birşeye benzetmek veyahut düşmanı muhasarasına dahi mecbur etmek daha hayırlı olacağı müsellemâttandır. Serdâr-ı ekrem hazretleri dahi bu kaziyye-i müsellemeye riayetle amel buyurarak meydan muharebesinden ictinâb ve bu bâbda icra-yı re'y-i sevâb buyurmuşlardır. Tuna sahilinden yevm-i müfârakatımızın yedinci günü Şumnu'ya muvasalat olundu.

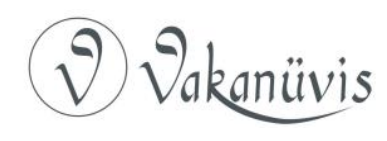




\section{Sonuç}

Tevfik Mustafa Paşa harp hatıralarını devrine göre oldukça sade bir Türkçeyle kaleme almıştır. Hatıra esasen taslak bir metindir. Bununla birlikte Kırım Harbi Tuna Cephesi'nde yürütülen askerî harekâtın detaylarını bu hatırada bulmak mümkündür. Bu yönüyle Kırım Harbi'ne dair Osmanlı / Türk tarih yazımının sınırlı literatürüne hatıranın önemli bir katkı sağlayacağı değerlendirilmektedir. Bu hatıra, Yeniçeriliğin kaldırılması sonrasında modernleşme sürecine giren Osmanlı ordusuna mensup subayların meslekî ve entelektüel düzeylerindeki değişimi yansıtması açısından da önemli bir vesikadır.

\section{Kaynakça}

\section{Arşiv Kaynakları}

Cumhurbaşkanlı̆̆ı Osmanlı Arşivi ( BOA),

Sadaret Mektubî Kalemi Nezaret ve Devair Evrakı (A. MKT. NZD.) 110/79, Bab-ı Asafi Vakanüvislik Kalemi Defteri (A. VKN.) 1, 19.

\section{Inceleme ve Araştırmalar}

Ahmed Muhtar Paşa, Kırım Harbi'nde Silistre Müdafaası 1853-1854 Tuna Seferi, yay. haz. Gültekin Yıldız - Fatih Tetik, Türkiye İ̧̧ Bankası Kültür Yayınları, İstanbul 2014.

Ahmed Nâfiz, Siliste Muhâsarası, Teodor Kasap Matbaası, i̇stanbul H 1290. Hüseyin Hüsnü, Sâ 'ika-i Zafer, ìstanbul H 1292.

Karal, Enver Ziya, "Zarif Paşa'nın Hatıratı”, Belleten, 4 (16), 1940, ss. 443 494.

Khaled, Fahmy, Paşanın Adamları, Kavalalı Mehmed Ali Paşa, Ordu ve Modern Mısır, İstanbul Bilgi Üniversitesi Yayınları, İstanbul, 2010.

Mehmed Süreyya, Sicill-i Osmani, C V, yay. haz. Nuri Akbayar, Tarih Vakfı Yurt Yayınları, ìstanbul, 1996.

Menemencioğlu Ahmed Bey, Menemencioğulları Tarihi, yay. haz. Yılmaz Kurt, Akçağ Yayınları, Ankara 1997.

Okay, M. Orhan, "Hâtırat", Türkiye Diyanet Vakfı islâm Ansiklopedisi, C XVI, ìstanbul 1997, ss. 445-449.

Özkırımlı, Atilla, Türk Edebiyatı Ansiklopedisi, 5. bs. , C I, Cem Yayınları, İstanbul 1990.

Uyar, Mesut - Erickson, Edward J. , Osmanlı Askeri Tarihi, Türkiye işs Bankası Kültür Yayınları, İstanbul, 2014.

Sir Adolphus Slade, Müşavir Paşa'nın Kırım Harbi Anıları, yay. haz. Candan Badem, Türkiye İş Bankası Kültür Yayınları, İstanbul, 2012.

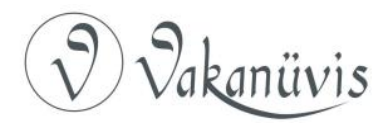




\section{Internet Kaynakları}

Taha Toros Arşivi, Dosya No: 640128, http://earsiv .sehir. edu.tr: 8080/ xmlui/bitstream/handle/11498/25577/001640128010.pdf?sequence=1\&isAll owed=y, e.t. 10.04.2019.

Taha Toros Arşivi, Dosya No: 551592, http://earsiv.sehir.edu.tr:8080 /xmlui/bitstream/handle/11498/26565/01551669007.pdf?sequence=1\&isAllo wed $=y$, e.t. 10.04.2019. 


\section{EKLER}

Ek-1 Tevfik Mustafa Paşa'nın Ahmed Cevdet Paşa'ya gönderdiği takrir ve harp hatıraları.

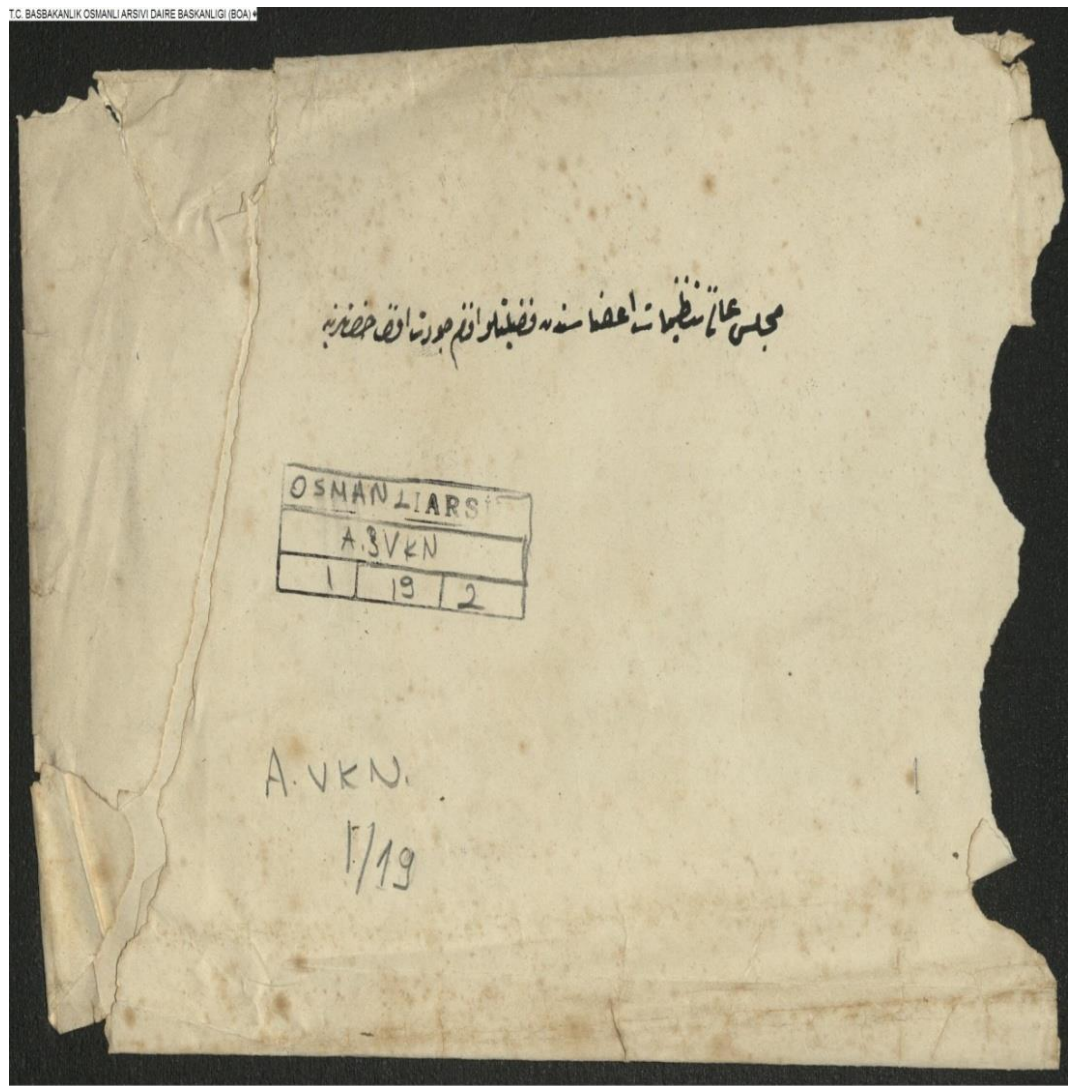

A.\}VKN.00001.00019.002 


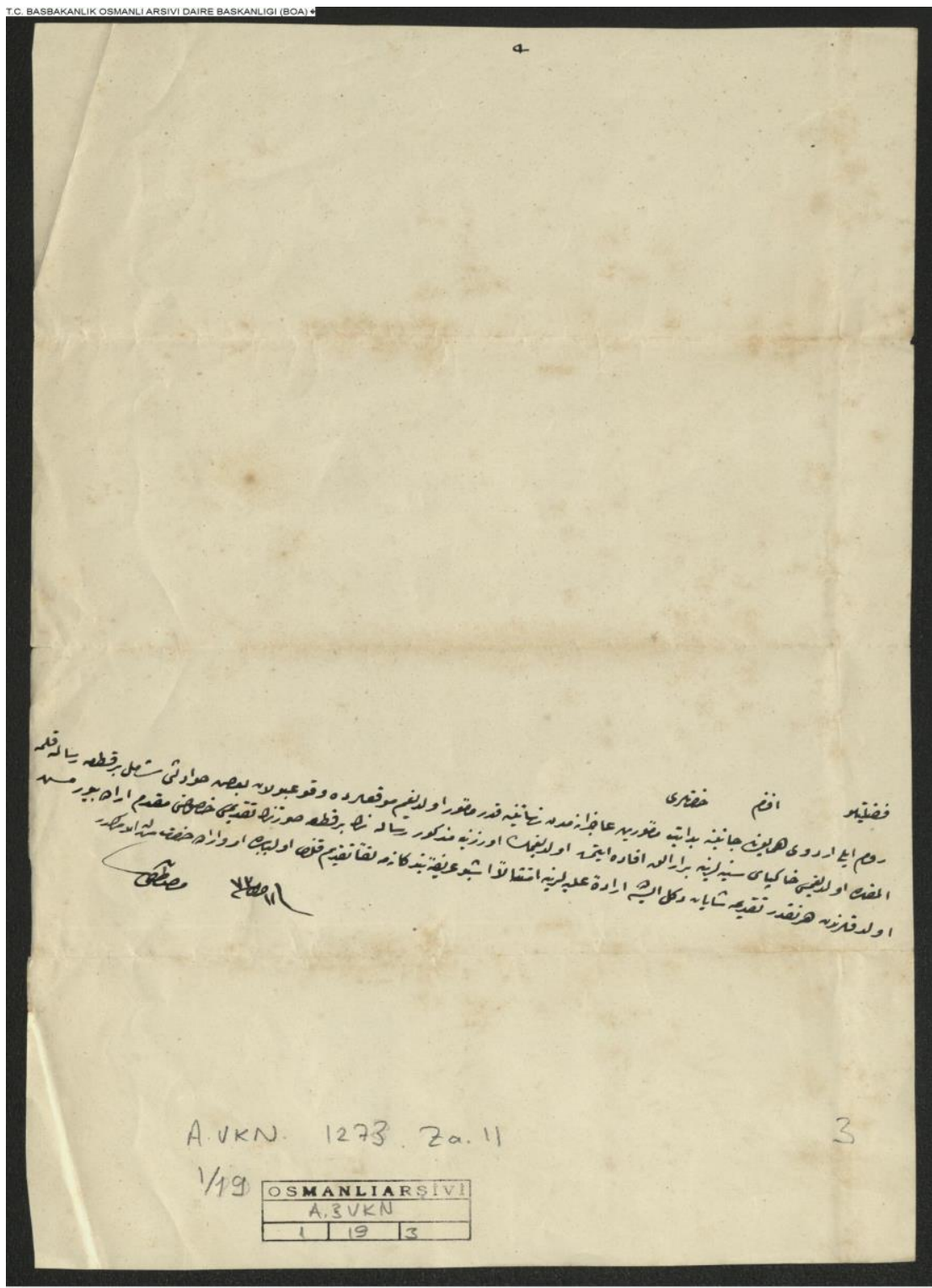

A.\} VKN.00001.00019.003

(9) Vakenüvis 


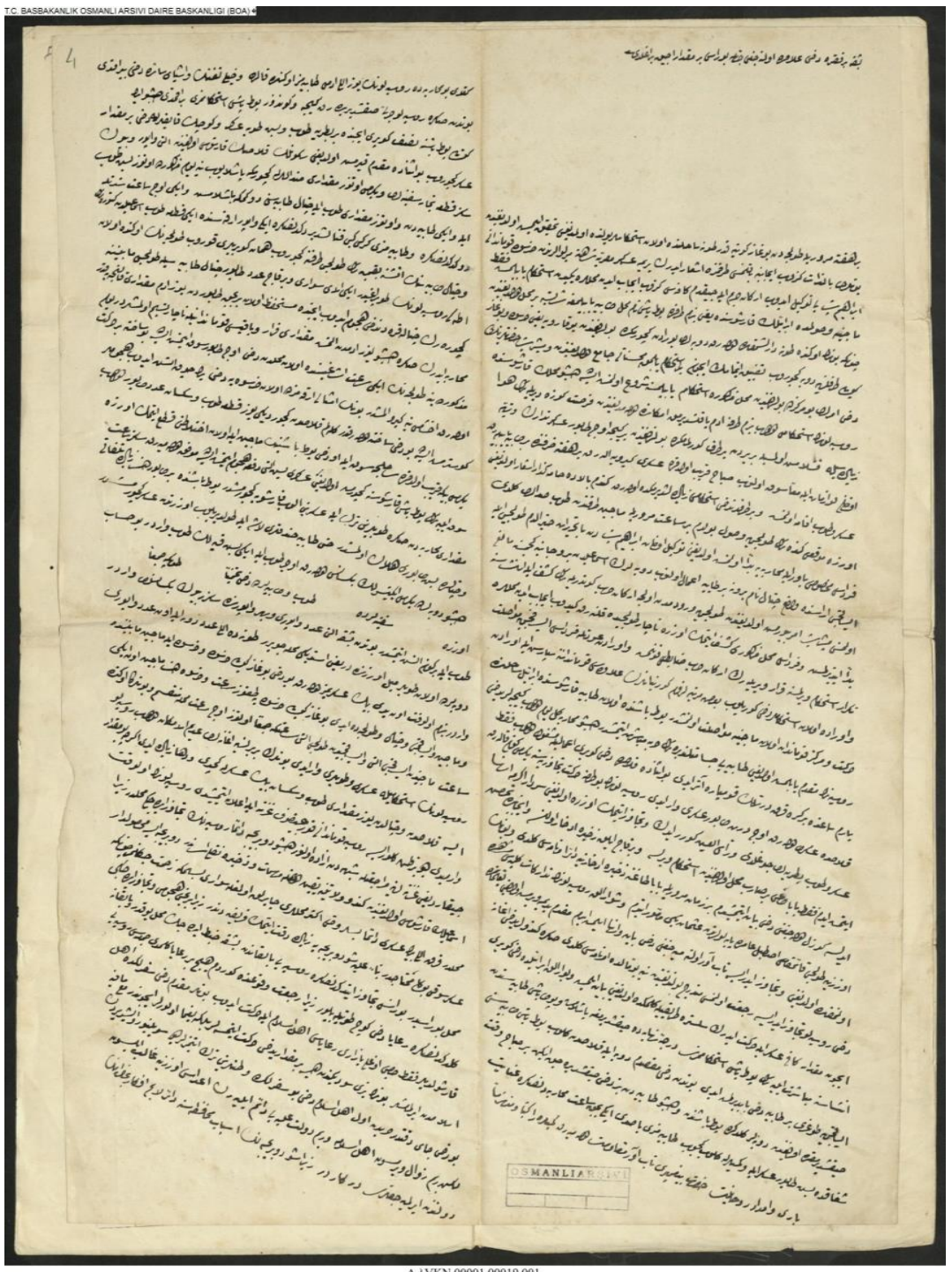

A.j VKN.00001.00019.001 
3 رون

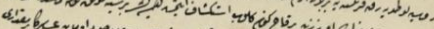

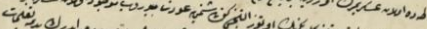

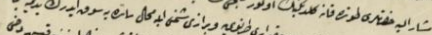
تا-بح

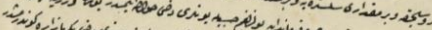

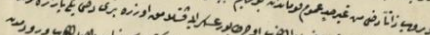

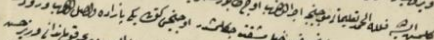

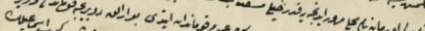

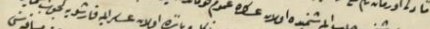

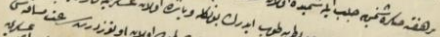

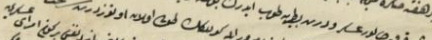

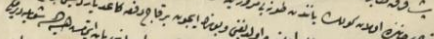

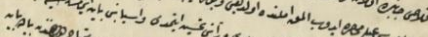
دون

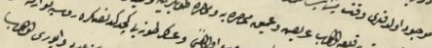
ا

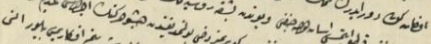

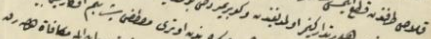

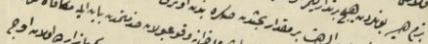

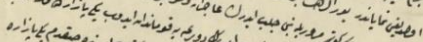

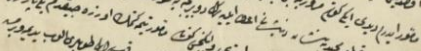

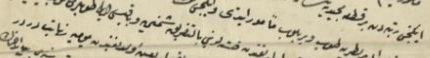

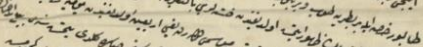

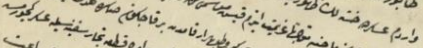

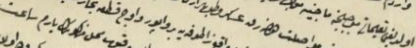
الوينه

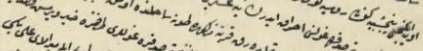

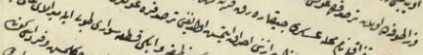
e Ci تصدئ ن ف

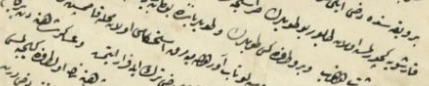
ו en:

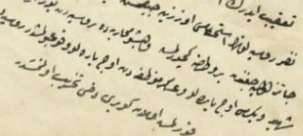

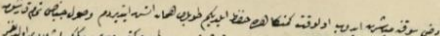

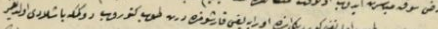

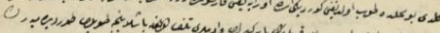

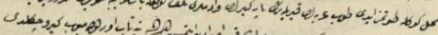

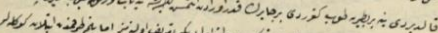

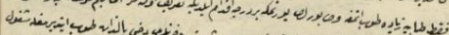

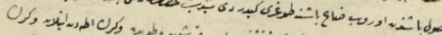

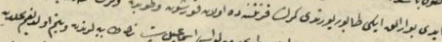

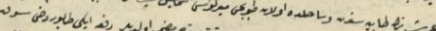

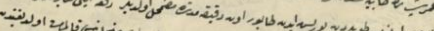

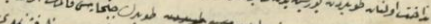

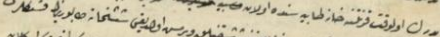

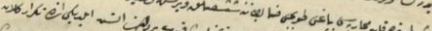
Chicen

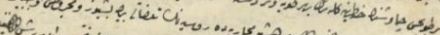

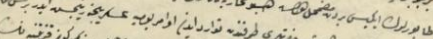

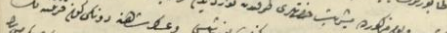

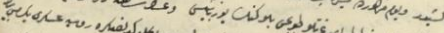

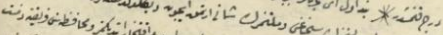

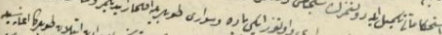

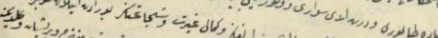
C.

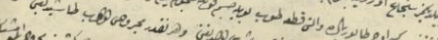

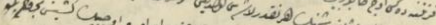

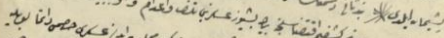

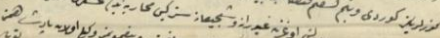
年 v.

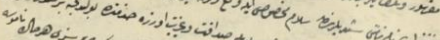

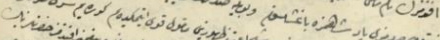

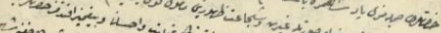

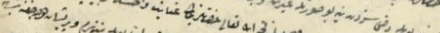
هi

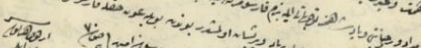

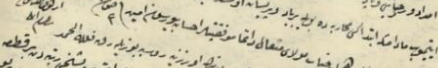
淀

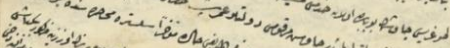

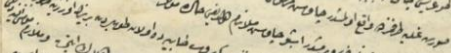

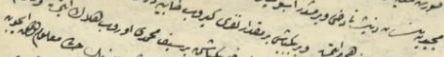

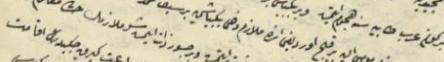

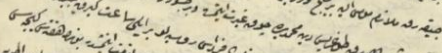

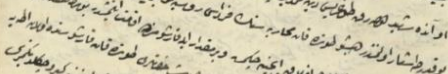

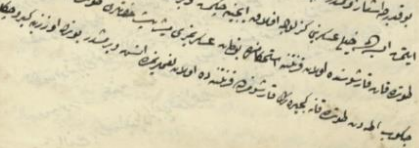

A.\}VKN.00001.00019.001 


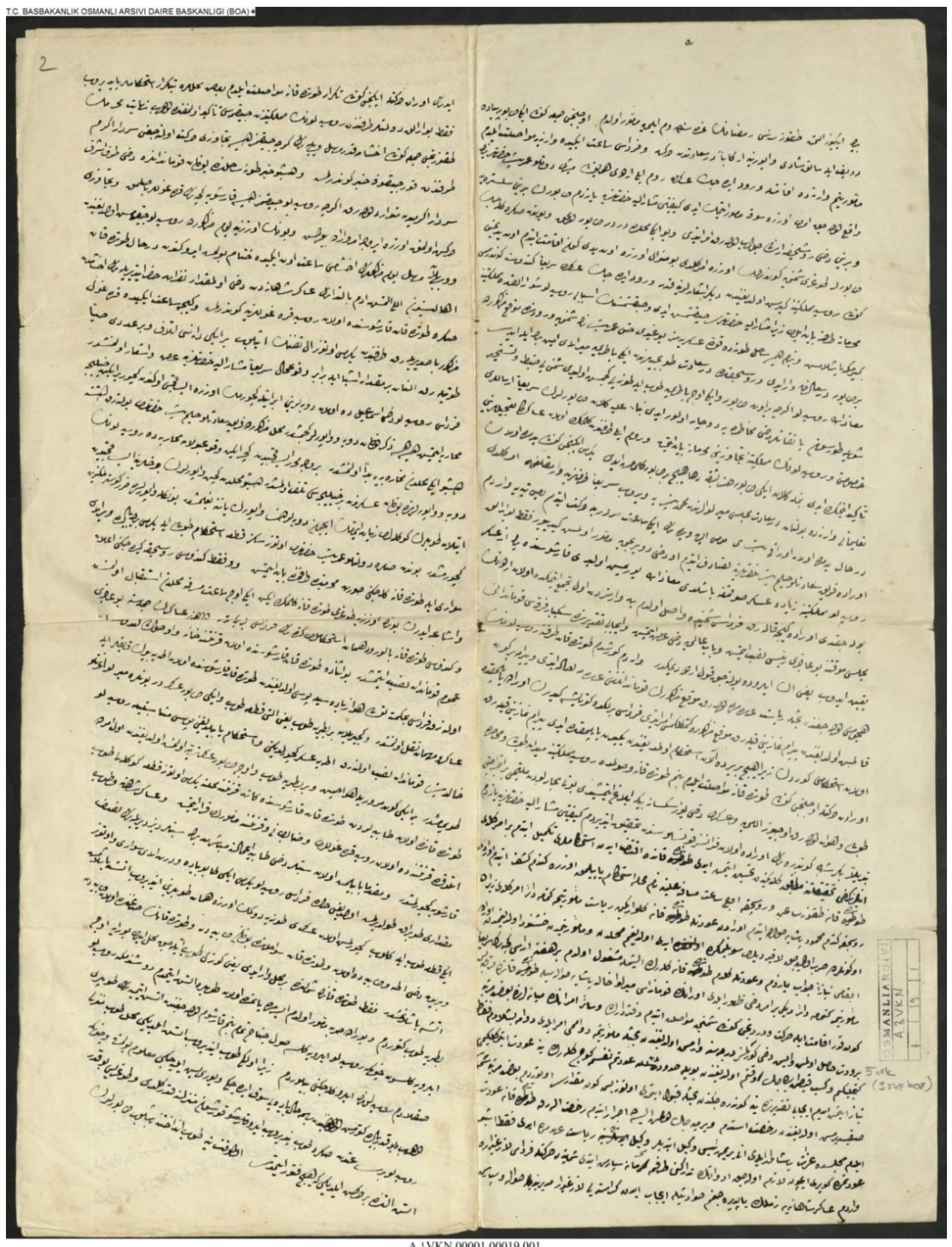

A. IVKN.00001.00019.001 


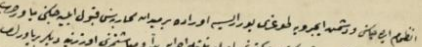

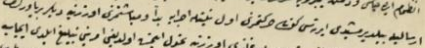

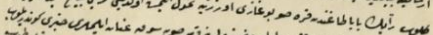
1

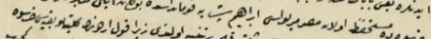

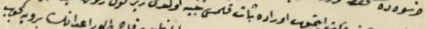

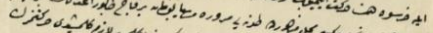

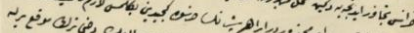

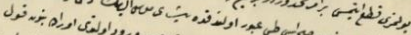

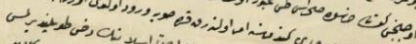

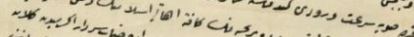

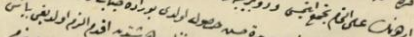

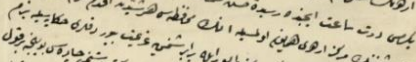

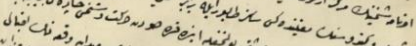
أن

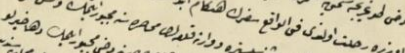

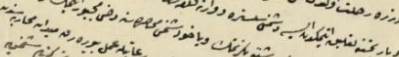

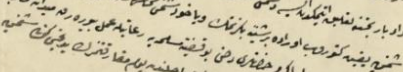
ا

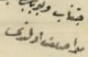

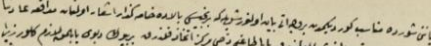

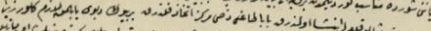

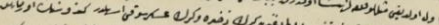

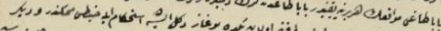

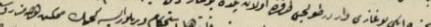

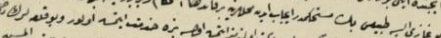
اجر

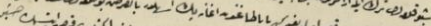

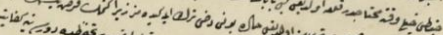

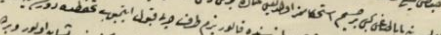

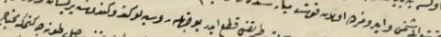

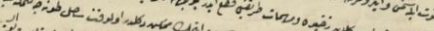

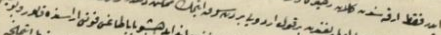

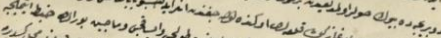

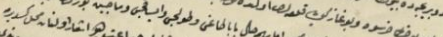

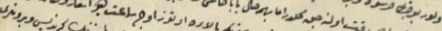
o ve

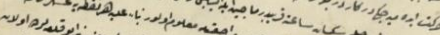

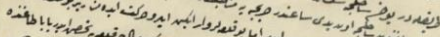

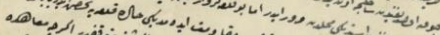

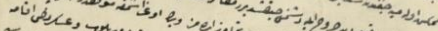

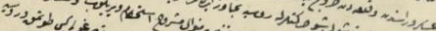
في

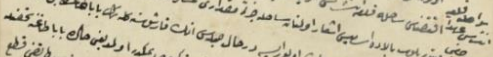

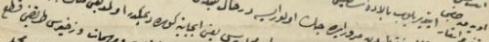

ثان

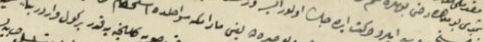
K.

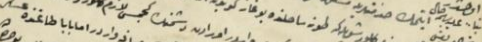
政

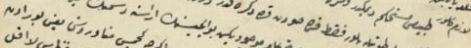
vilo $c_{i} c_{i} c_{1}$

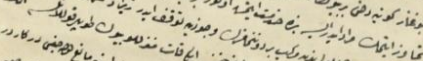
No

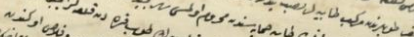
מا

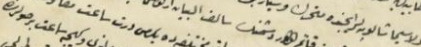

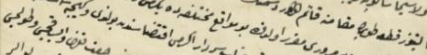

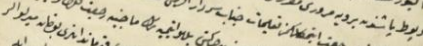

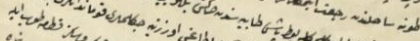

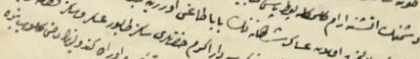
$1 / 19$ 